\title{
Biology of the Triple-Negative Breast Cancer: Immunohistochemical, RNA, and DNA Features
}

\author{
Mercedes Herrera Juarez Pablo Tolosa Ortega Ana Sanchez de Torre \\ Eva Ciruelos Gil \\ Division of Gyneco-Oncology, Breast Cancer Unit, University Hospital 12 de Octubre, Madrid, Spain
}

\section{Keywords}

Triple-negative breast cancer · Intrinsic subtypes .

Biomarkers $\cdot$ Immuno-oncology

\begin{abstract}
Background: The triple-negative breast cancer (TNBC) constitutes a heterogeneous disease with an aggressive behavior and a poor prognosis. A better understanding of its biology is required to identify new biomarkers and improve clinical outcomes. Summary: To date, the definition and classification of TNBC depends on a multiomic approach including immunohistochemistry (IHC), genomic, and transcriptomic features, and the tumor immune landscape. The development of new technologies has allowed us to sequence the whole cancer genome. The Cancer Genome Atlas (TCGA) and next-generation sequencing have led to a greater knowledge of DNA alterations such as TP53 or BRCA mutations, copy number variations, and DNA methylations. In addition, gene expression profiling has allowed to define a molecular intrinsic classification of TNBC based on mRNA. IHC and genomic profiling are also necessary to identify new immune biomarkers such as the presence of tumor-infiltrating lymphocytes and the expression of immune checkpoint molecules. Key Messages: This review aimed to provide recent knowledge of TNBC biology and classification focused on IHC, transcriptomics, genomic features, and the new immune biomarkers.
\end{abstract}

(c) 2020 S. Karger AG, Basel

\section{Introduction}

Triple-negative breast cancer (TNBC) is a heterogeneous disease with a poor prognosis, defined by the absence of estrogen receptor (ER), progesterone receptor (PR), and HER2 protein overexpression [1]. TNBC represents $10-15 \%$ of all breast tumors and is characterized by poorer survival, the lack of solid biomarkers, and absence of personalized targeted therapy.

TNBC patients are at high risk of relapse in the first 5 years, especially if a pathological complete response (pCR) has not been obtained [2], despite the use of conventional chemotherapy based on anthracycline and taxane regimens, the addition of platinum agents, and the use of adjuvant capecitabine [3]. It is known that stage I tumors with stromal tumor-infiltrating lymphocytes (TILs) $>30 \%$ have an excellent prognosis without adjuvant treatment [4]. However, those patients who relapse early or progress during neoadjuvant chemotherapy (NACT) represent a real unmet medical need.

Beyond the classical definition of TNBC, we should analyze TNBC with a multiomic approach including immunohistochemistry (IHC), transcriptomics, genomics, and new immune biomarkers. Breast cancer intrinsic subtypes play an essential role to classify these tumors. We know that within TNBC all intrinsic subtypes can be identified. The aim of this review is to provide a multiomic approach to TNBC. 


\section{Histological and IHC Approach}

We can dissect TNBC by morphological and IHC features. Several approaches such as histological grade or the presence of favorable histology (medullary breast carcinoma or adenoid cystic carcinoma) or aggressive histology (metaplastic carcinomas or sarcomatous carcinomas) could guide our initial decision. The IHC analysis is essential in TNBC definition, as well as the Ki-67 proliferation index, the presence of androgen receptor (AR) and basal cytokeratins, and programmed death-ligand 1 (PD-L1) expression.

\section{Ki-67}

To evaluate cell proliferation rates, $\mathrm{Ki}-67$ expression is the most used cell membrane antigen and is considered a prognostic biomarker in breast cancer (BC). Ki-67 expression $>20 \%$ is found in up to $50 \%$ of TNBC and used to be higher than in luminal $\mathrm{BC}$ [5]. Recently, a retrospective study showed that higher Ki-67 expression is an independent prognostic factor in disease-free survival (DFS; RR 2.83, 95\% CI: $1.58-5.06, p<0.001$ ) and OS (RR $3.18,95 \%$ CI: $1.48-6.79, p=0.003$ ) [6], and it is significantly correlated with the TNBC phenotype [7]. After NACT, patients with Ki-67 expression increasing $\geq 20 \%$ had a worse DFS than patients with stable or decreased Ki-67 expression $(p<0.001)$ [8].

\section{Androgen Receptor}

AR expression is another important marker. AR expression in TNBC may vary widely between 10 and $90 \%$ according to the cohort and the cutoff used for AR positivity $(\geq 1$ or $>10 \%)[9,10]$. Within non-basal-like TNBC, AR could be a predictive response biomarker. In TNBC cell lines with positive AR expression, AR stimulation results in growth activation while AR antagonists promote growth decline [11]. Recently, 2 phase II trials have been published demonstrating the activity of abiraterone acetate plus prednisone and enzalutamide in AR-positive TNBC patients $[12,13]$. Despite these findings, the development of antiandrogens in this subset has not been correctly established due to the absence of a homogeneous definition for AR positivity and the low rate of AR positivity withing TNBC. However, interest in this file is growing, and new trials are guaranteed.

\section{Epidermal Growth Factor Receptor}

The epidermal growth factor receptor (EGFR) plays an important role in cell proliferation and apoptosis inhibition. EGFR overexpression in TNBC is variable among studies ranging from 13 to $78 \%[14,15]$. Data from EGFR protein overexpression in triple-negative cancer is controversial and has not been confirmed as a prognostic bio- marker. Targeting this pathway by tyrosine kinase inhibitors, such as gefitinib, afatinib, and erlotinib, or by monoclonal antibodies such as cetuximab and panitumumab $[16,17]$, has not demonstrated any sign of clinical activity.

\section{Basal Cytokeratins}

Basal-like BC represents $75 \%$ of TNBC and is considered an aggressive subtype defined classically by basal cytokeratins: CK 5/6, CK 14, and CK 17 [18]. CK 5/6 expression ranges from 24 to $72 \%$ in TNBC $[19,20]$, CK 14 and CK 17 overlaps with CK 5/6. Some results suggested that CK 5/6-positive TNBC have poorer prognosis; despite that, the CIBOMA trial showed that a nonbasal phenotype according to CK 5/6 and/or EGFR expression by IHC resulted in a significantly increased DFS (HR, 0.53; $95 \%$ CI, $0.31-0.91 ; p=0.022$ ) and overall survival (OS) (HR, 0.42; 95\% CI, 0.21-0.81; $p=0.0095)$ when capecitabine therapy was used [21].

\section{DNA: Mutation, Copy Number Variation, and Methylation}

The Cancer Genome Atlas (TCGA) analyzed primary BC by genomic DNA copy number arrays, DNA methylation, exome sequencing, messenger RNA arrays, microRNA sequencing, and reverse-phase protein arrays [22]. Despite the large number of genes traditionally mutated in BC (PIK3CA, PTEN, AKT1, TP53, GATA3, CDH1, RB1, MLL3, MAP3K1, and CDKN1B) and novel significantly mutated genes (TBX3, RUNX1, CBFB, AFF2, PIK3R1, PTPN22, PTPRD, NF1, SF3B1, and CCND3) and the high tumor mutational burden (TMB), the diversity and recurrence of mutated genes in TNBC is lower than in luminal subtypes. TP53 mutations occur in $80 \%$ of TNBC followed by PIK3CA mutations (9\%), while other driver mutations are quite infrequent.

\section{TP53}

TP53 mutations in TNBC were mostly nonsense or frame shift mutations, and they occur in $65-80 \%$ of cases [23]. p53 protein expression in TNBC tumor tissue changes according to the type of mutation occurring in the TP53 gene: missense mutations tend to show high $\mathrm{p} 53$ protein expression and increased protein stability, which is in contrast with deletion mutations that lead to a lack of protein expression. Mutant p53 cannot be recommended as a prognostic or therapy-predictive biomarker in $\mathrm{BC}$ and has been considered as undruggable. Despite that, several compounds have become available, and they can reactivate mutant $\mathrm{p} 53$ protein and convert it to a conformation with wild-type properties. Some of these compounds, especially PRIMA-1, PRIMA-1 met (APR-246) PK11007, and 
COTI-2, have been found to exhibit anticancer activity in preclinical BC models, and clinical trials are guaranteed [24].

\section{PI3K/AKT/mTOR Signaling Pathway}

Despite the low mutation rate in the PIK3CA gene (5$13 \%$ ) $[23,25]$, the PI3K/AKT/mTOR (phosphoinositide 3 -kinase/protein kinase $\mathrm{B} / \mathrm{mammalian}$ target of rapamycin)-dependent pathway is one of the most important pathways associated with TNBC. PTEN (phosphatase and tensin homologue), INPP4B (inositol polyphosphate 4-phosphatase type II), and other phosphatases are key regulators of this pathway [26] Mutated or lost PTEN occurs in $35-50 \%$ of cases and INPP4B loss in 30\% [27]. AKT activation is a potential predictive biomarker to AKT inhibitors being pAKT an activity marker [27] with a low mutation rate; MAGI3-AKT3 translocation occurs in $7 \%$ of TNBC and led to constitutive AKT3 activation [28]. LOTUS and PAKT phase II trials have suggested that this pathway may be successfully targeted. The addition of an AKT inhibitor to paclitaxel as first-line therapy for metastatic TNBC improved progression-free survival (PFS) over placebo (stratified HR 0.59; 95\% CI: 0.26-1.32, $p=0.018$ ) in patients who harbored some alterations in this pathway [29]. Similar findings have been published recently with capivasertib (HR, 0.30 ; 95\% CI, 0.11-0.79; 2 -sided $p=0.01$ ) [30]. Phase III trials with AKT inhibitors in TNBC are ongoing (NCT03997123, NCT03337724, and NCT04177108).

\section{$B R C A$}

Approximately $20 \%$ of TNBC had a BRCA1/2 mutation (12\% germline and $8 \%$ somatic). Additionally, homologous recombination deficiency as well as genetic and epigenetic inactivation of other components can occur in sporadic cancers (PALB2, BARD1, BRIP1, RAD51B, RAD51C, RAD51D, ATM, FAAP20, CHEK2, FAN1, FANCE, FANCM, and POLQ), defined as "BRCAness" condition [31]. BRCA1/2 mutations and "BRCAness" condition determine a greater sensitivity to platinum chemotherapy as well as to inhibitors of the DNA repair enzyme poly-ADP ribose polymerase 1 (PARP). Both talazoparib and olaparib are indicated in HER2-negative metastatic BC with BRCA1/2 germinal mutations based on 2 randomized phase 3 trials [32, 33]. In a small neoadjuvant trial for germline BRCA $1 / 2$ mutated and localized BC, talazoparib achieves 53\% pCR rate and residual cancer burden 0 or 1 in $63 \%$ of them [34].

\section{Copy Number Variation}

In a 465 primary TNBC cohort, MYC was the most frequently affected gene by somatic copy number variation (gained in $81 \%$ of patient samples), with frequent gains in E2F3 (55\%), CCNE1 (47\%), EGFR (47\%), CCND1 (44\%), and MYB (41\%), and frequent losses in CHD1 (lost in $71 \%$ of samples), PTEN (58\%), RB1 (54\%), and CDKN2A (43\%), similarly to the TCGA cohort $[22,35]$.

\section{DNA Methylation}

Finally, DNA methylation is another strong biomarker for TNBC. The TCGA identified 5 distinct DNA methylation groups. Group 5 showed the lowest levels of DNA methylation, overlapped with the basal-like mRNA subtype, and showed a high frequency of TP53 mutations. BRCA1 promoter methylation was associated with poorer OS and recurrence-free survival in TNBC, and is under evaluation as a predictive response biomarker of PARP inhibitors in clinical trials [36]. Using whole-genome DNA methylation analysis, we can divide TNBC into 3 prognostic subgroups, correlate DNA methylation with TNBC gene expression, and predict higher pCR rates after NACT $[37,38]$.

\section{Molecular BC Classification Based on mRNA}

Analysis of gene expression profiles from $\mathrm{BC}$ was carried out by Perou et al. [39] and classified tumors into 5 clusters, called intrinsic subtypes: luminal-A, luminal-B, HER2-enriched, basal-like, and a normal-like BC group. These entities show significant differences in incidence, survival, and response to therapy [40]. Although both clinical and biological features distinguish the 5 intrinsic subtypes, relevant variation exists within each group [41]. Additional gene expression analyses have demonstrated the presence of a new intrinsic subtype, claudin low, representing $7-14 \%$ of all BCs [42]. Clinically, the majority of claudin-low tumors are TNBC (70\%), with a high frequency of metaplastic and medullary differentiation. Although claudin-low and basal-like subtypes share low luminal and HER2 gene expression, claudin-low tumors also show low expression of proliferation-associated genes, in contrast to basal-like subtype.

\section{Molecular TNBC Subtypes}

TNBC is not a single entity but a very heterogeneous disease that can be classified into different molecular subtypes by gene expression profiling. The first effort to molecularly classify TNBC subtypes was a direct comparison of 374 TNBC samples extracted from 14 data sets where investigators tried to establish the relationship between the PAM50 intrinsic subtypes [39] and TNBC molecular subtypes [43]. The majority of the TNBC samples were classified by PAM50 assay as basal like (80.6\%), followed by the HER2-enriched intrinsic subtype (10.2\%), normallike $(4.6 \%)$, luminal-B (3.5\%), and luminal-A subtypes (1.1\%; Table 1) [44]. 
Table 1. BC intrinsic subtypes and TNBC subtypes based on gene expression profiles

\begin{tabular}{|c|c|c|c|}
\hline $\begin{array}{l}\text { BC intrinsic } \\
\text { subtypes } \\
\text { Perou et al. [39] }\end{array}$ & $\begin{array}{l}\text { TNBC type } \\
\text { Lehman et al. [45] }\end{array}$ & $\begin{array}{l}\text { TNBC type } 4 \\
\text { Lehman et al. [47] }\end{array}$ & $\begin{array}{l}\text { TNBC subtypes } \\
\text { Burstein et al. [48] }\end{array}$ \\
\hline $\begin{array}{l}\text { Basal like } \\
\text { Her2 enriched } \\
\text { Luminal A } \\
\text { Luminal B } \\
\text { Claudin low } \\
\text { Normal like }\end{array}$ & $\begin{array}{l}\text { Basal like } 1 \text { (BL1) } \\
\text { Basal like } 2 \text { (BL2) } \\
\text { Immunomodulatory (IM) } \\
\text { Mesenchymal (M) } \\
\text { Mesenchymal stem like (MSL) } \\
\text { Luminal androgen receptor (LAR) } \\
\text { Unstable (UNS) }\end{array}$ & $\begin{array}{l}\text { Mesenchymal }(\mathrm{M}) \\
\text { Luminal androgen receptor (LAR) }\end{array}$ & $\begin{array}{l}\text { Basal like, immune suppressed (BLIS) } \\
\text { Basal like, immune activated (BLIA) } \\
\text { Mesenchymal (MES) } \\
\text { Luminal androgen receptor (LAR) }\end{array}$ \\
\hline
\end{tabular}

The emergence of gene expression profiles allowed Lehman et al. [45] to divide TNBC into 6 distinct subtypes: basal-like 1 and 2 (BL1 and BL2), mesenchymal (M), mesenchymal stem-like (MSL), immunomodulatory (IM), and luminal androgen receptor (LAR). Then, an unstable subtype was also included [45]. These subtypes are characterized by different patterns of molecular alterations in terms of RNA expression, somatic mutations, and copy number variation that tend to cluster in genes involved in specific pathways. After neoadjuvant therapy of early TNBC tumors, the BL1 subtype had the highest pCR rate $(52 \%)$, while BL2 and LAR had the lowest ( 0 and $10 \%$, respectively). Lehman subtypes seem to be able to predict pCR probability better than PAM50 intrinsic subtypes [46].

Using more advanced laboratory techniques, Lehmann et al. [47] have subsequently demonstrated that the presence of stromal cells in tumor specimens (TILs and tumorassociated mesenchymal cells) affects the definition of the IM and MSL subtypes, respectively. This led to a new classification, TNBC type 4 , including 4 stable transcriptional subtypes (BL1, BL2, M, and LAR). Additionally, the 4 TNBC subtypes showed significant differences in pCR rate when treated with standard NACT, with $46 \%$ of BL1 patients reaching pCR, compared to 12,29 , and $15 \%$ for patients with BL2, M, and LAR subtypes, respectively ( $p=$ 0.04). In the meantime, Burstein et al. [48] described stable molecular TNBC phenotypes using gene expression profiling. They distinguish 4 subtypes: LAR, mesenchymal (MES), basal-like, immune suppressed (BLIS), and basallike, immune activated (BLIA). Interestingly, the BLIS subtype showed the worst prognosis, and the BLIA subgroup conferred the best outcome in terms of DFS.

\section{TNBC Subtypes according to Molecular Profiling}

The BL1 subtype is heavily enriched in genes involved in DNA damage response (ATR/BRCA) and cell division pathways, including the highest rate of TP53 mutations (92\%), high gain/amplifications of MYC and CDK6, and deletions in BRCA2, PTEN, MDM2, and RB1 [49]. The highly proliferative nature of this entity is further associated with high Ki-67 mRNA expression. Enrichment of proliferation genes and increased Ki-67 expression in basal-like TNBC tumors suggest that antimitotic agents such as taxanes could be a useful therapeutic strategy [50]. The BL2 subtype involves high levels of growth factor signaling and metabolic pathways (EGF, NGF, MET, Wnt/ $\beta$-catenin, and IGF1R). Genes related with immune cell processes, such as $\mathrm{B}$ - and T-cell receptor signaling, antigen presentation, and cytokine pathways (JAK/STAT, TNF, and NFkB) are highly expressed in the IM subtype. Both mesenchymal TNBC subtypes and MSL share high expression of genes related to the epithelial-mesenchymal transition and growth factor pathways. However, only the MSL subtype has low expression of proliferation genes. This decreased proliferation is attached to high expression of genes associated with stem cells. The MSL subtype also displays low expression of claudins 3, 4, and 7, consistent with the claudin-low subtype of BC [42]. Finally, the LAR subtype is the most different among the TNBC subtypes. Despite ER negativity, these tumors are enriched in hormonally regulated pathways (FOXA1 and GATA3) and mRNA and proteins of AR. Thus, not surprisingly, LAR tumors frequently present mutations in PIK3CA (55\%), KMT2C (19\%), CDH1 (13\%), NF1 (13\%), and AKT1 (13\%) [45].

\section{Immune Characterization and Immuno-Oncology Biomarkers in TNBC}

Immunotherapy, and particularly immune checkpoint blockade, is a promising therapy that has shown to improve outcome in solid malignancies. The poor prognosis and the lack of biomarkers and targeted therapy in TNBC have encouraged basic and translational research in the field of immunotherapy. TNBC is characterized by different immune microenvironments from other subtypes, with a higher density of lymphocytic infiltrates and PD-L1 expression, which may involve clinical and therapeutic impact. 
Table 2. Relevant neoadjuvant (a) or adjuvant studies (b) reporting lymphocyte-predominant breast cancer (LPBC) incidence and achieved outcomes

a Relevant neoadjuvant studies

\begin{tabular}{|c|c|c|c|c|c|c|c|}
\hline First author, year & Design & Histology & Chemotherapy & LPBC & $\begin{array}{l}\text { Tumors } \\
\text { with LPBC } \\
\text { phenotype }\end{array}$ & Outcome LPBC & Outcome non-LPBC \\
\hline $\begin{array}{l}\text { Denkert [57], 2010: } \\
\text { patients from the } \\
\text { GeparDuo trial }\end{array}$ & Retrosp. & $\begin{array}{l}\text { ER-I } \\
\text { PR- }\end{array}$ & $\begin{array}{l}\text { Docetaxel } \mathrm{DD}+\text { doxorubicin vs. } \\
\text { doxorubicin }+\mathrm{CP}->\text { docetaxel }\end{array}$ & $>60 \%$ & $14.9 \%$ & pCR $42.9 \%$ & $\begin{array}{l}\text { pCR (focal lympho- } \\
\text { cytes) } 19.4 \% \\
\text { pCR (no lymphocytes) } \\
25 \%\end{array}$ \\
\hline $\begin{array}{l}\text { Issa-Nummer [59], 2013: } \\
\text { study PREDICT, from } \\
\text { the GeparQuinto trial }\end{array}$ & Prosp. & Her2- & $\begin{array}{l}\text { Epirubicin, } \mathrm{CP}->\text { taxane } \pm \\
\text { bevacizumab, everolimus, or } \\
\text { lapatinib }\end{array}$ & $>60 \%$ & $26.2 \%$ & pCR $36.6 \%$ & pCR $14.3 \%$ \\
\hline $\begin{array}{l}\text { Denkert [60], 2015: } \\
\text { patients from the } \\
\text { GeparSixto trial }\end{array}$ & Prosp. & TNBC & $\begin{array}{l}\text { Paclitaxel }+ \text { liposomal } \\
\text { doxorubicin }+ \\
\text { bevacizumab } \pm \text { CBDCA }\end{array}$ & $>60 \%$ & $28.3 \%$ & $\begin{array}{l}\text { pCR } 74 \% \text { with } \\
\text { CBDCA vs. } 43 \% \\
\text { without CBDCA }\end{array}$ & $\begin{array}{l}\text { pCR } 46 \% \text { with CBDCA } \\
\text { vs. } 34 \% \text { without CB- } \\
\text { DCA }\end{array}$ \\
\hline $\begin{array}{l}\text { Herrero-Vicent [61], } \\
2017\end{array}$ & Retrosp. & TNBC & Anthracycline and taxane & $>40 \%$ & $35.4 \%$ & $\begin{array}{l}\text { pCR } 87 \% \\
\text { 3-year DFS: } 98 \%\end{array}$ & $\begin{array}{l}9.4 \% \\
\text { 3-year DFS: } 70 \%\end{array}$ \\
\hline $\begin{array}{l}\text { Denkert [58], 2018: } \\
\text { patients from the } \\
\text { GeparTrio trial }\end{array}$ & Retrosp. & HER2- & $\begin{array}{l}\text { TAC } \times 2->4 \text { vs. } 6 \text { of TAC in re- } \\
\text { sponders or TAC } \times 4 \text { followed } \\
\text { by VNR and capecitabine } \times 4 \text { for } \\
\text { nonresponders }\end{array}$ & $>60 \%$ & $12 \%$ & pCR $48.1 \%$ & $\begin{array}{l}8 \% \text { (no lymphocytes) - } \\
14 \% \text { (focal lympho- } \\
\text { cytes) }\end{array}$ \\
\hline $\begin{array}{l}\text { O’Loughlin [51], } \\
2018\end{array}$ & Prosp. & TNBC & $\begin{array}{l}\text { Anthracycline and taxane or } \\
\text { anthracycline, taxane, and } \\
\text { CBDCA }\end{array}$ & $>50 \%$ & $12 \%$ & pCR $89 \%$ & pCR $47 \%$ \\
\hline
\end{tabular}

b Relevant adjuvant studies

\begin{tabular}{|c|c|c|c|c|c|c|c|c|}
\hline Trial & Design & Histology & Chemotherapy & $\begin{array}{l}\text { Median } \\
\text { TILs }\end{array}$ & LPBC & $\begin{array}{l}\text { Tumors } \\
\text { with LPBC } \\
\text { phenotype }\end{array}$ & $\begin{array}{l}\text { Outcome (per } 10 \% \\
\text { increase in lympho- } \\
\text { cye infiltration) }\end{array}$ & Other outcomes \\
\hline $\begin{array}{l}\text { Loi [52], 2013: } \\
\text { patients from the } \\
\text { BIG 02-98 trial }\end{array}$ & Retrosp. & TNBC & $\begin{array}{l}\text { Doxorubicin }->\text { CMF or } \\
\text { doxorubicin }+ \text { CP }-> \\
\text { CMF vs. doxorubicin }+ \\
\text { docetaxel }->\text { CMF or } \\
\text { doxorubicin }->\text { docetaxel } \\
\text { followed by CMF }\end{array}$ & $\begin{array}{l}10 \% \\
\text { (sTILS) } \\
2 \% \text { (iTILS) }\end{array}$ & $>50 \%$ & $10.6 \%$ & $\begin{array}{l}17 \% \text { reduction in } \\
\text { the risk of relapse } \\
27 \% \text { reduction in } \\
\text { the risk of death }\end{array}$ & $\begin{array}{l}\text { 5-year DFS: } 92.3 \% \\
\text { LPBC vs. } 61.9 \% \text { non- } \\
\text { LPBC } \\
\text { 5-year OS: } 92.3 \% \text { LPBC } \\
\text { vs. } 71.0 \% \text { non-LPBC }\end{array}$ \\
\hline $\begin{array}{l}\text { Loi [53], 2014: } \\
\text { patients from the } \\
\text { FinHER trial }\end{array}$ & Retrosp. & TNBC & $\begin{array}{l}\text { Docetaxel or VNR } \times 3-> \\
\text { FEC } \times 3\end{array}$ & - & $>50 \%$ & $14.3 \%$ & $\begin{array}{l}21 \% \text { reduction in } \\
\text { the risk of distant } \\
\text { recurrence } \\
20 \% \text { reduction in } \\
\text { the risk of death }\end{array}$ & \\
\hline $\begin{array}{l}\text { Adams [54], 2014: } \\
\text { patients from } \\
\text { ECOG } 2197 \text { and } \\
\text { ECOG } 1199 \text { trials }\end{array}$ & Retrosp. & TNBC & $\begin{array}{l}\text { E2197: doxorubicin }+ \\
\text { CP vs. docetaxel } \times 4 \\
\text { E1199: doxorubicin }+ \\
\mathrm{CP} \times 4->\text { different } \\
\text { taxane regimens }\end{array}$ & $\begin{array}{l}10 \% \\
\text { (sTILS) } \\
0 \% \text { (iTILS) }\end{array}$ & $>50 \%$ & $4.4 \%$ & $\begin{array}{l}18 \% \text { reduction in } \\
\text { the risk of distant } \\
\text { recurrence } \\
19 \% \text { reduction in } \\
\text { the risk of death }\end{array}$ & \\
\hline $\begin{array}{l}\text { Pruneri [55], 2016: } \\
\text { from the IEO } \\
\text { Breast Cancer } \\
\text { Database }\end{array}$ & Retrosp. & TNBC & $\mathrm{CMF}$ or $\mathrm{CMF}+\mathrm{AC}$ & $20 \%$ & $>50 \%$ & $21.9 \%$ & $\begin{array}{l}21 \% \text { reduction in } \\
\text { the risk of distant } \\
\text { recurrence } \\
21 \% \text { reduction in } \\
\text { the risk of death }\end{array}$ & $\begin{array}{l}10 \text {-year DFS (LPBC) } \\
71 \% \\
10 \text {-year DDFS (LPBC) } \\
84 \% \\
10 \text {-year OS (LPBC) 96\% }\end{array}$ \\
\hline $\begin{array}{l}\text { Kotoula [56], 2016: } \\
\text { patients from } \\
4 \text { prospective trials }\end{array}$ & Retrosp. & TNBC & $\begin{array}{l}\text { Anthracycline - } \\
\text { taxane regimens }\end{array}$ & $\begin{array}{l}7 \% \text { sTILS } \\
\text { (all tu- } \\
\text { mors) }\end{array}$ & $>50 \%$ & $26 \%$ & - & $\begin{array}{l}\text { 7-year DFS: } 96.3 \% \\
\text { (LPBC) vs. } 72.8 \% \\
\text { (non-LPBC) } \\
\text { 7-year OS: } 100 \% \\
\text { (LPBC) vs. } 76.3 \% \\
\text { (non-LPBC) }\end{array}$ \\
\hline
\end{tabular}

sTILs, stromal tumor-infiltrating lymphocytes; iTIL, intratumoral tumor-infiltrating lymphocytes; DD, dose dense; CP, cyclophosphamide; TAC, docetaxel, doxorubicin, and cyclophosphamide; VNR, vinorelbine; CBDCA, carboplatin; CMF, cyclophosphamide, methotrexate, and fluorouracil; FEC, fluorouracil, epirubicin, and cyclophosphamide; AC, Adriamycin and cyclophosphamide; pCR, pathological complete response; DFS, disease-free survival; DDFS, distant DFS; OS, overall survival. 


\section{Tumor-Infiltrating Lymphocytes}

TILs are lymphocytes which can be found both surrounding the tumoral cells (stromal TILs) or in intimate contact with tumor cells (intratumoral TILs). Tumors with more than 50\% [51-56] to 60\% [51, 57-61] lymphocytic infiltrates have been defined as lymphocyte-predominant BC and represent about $20 \%$ of TNBC, in contrast to $16 \%$ in human HER2+ tumors and 6\% in luminal subtypes [62].

The presence of pCR after NACT is strongly correlated with long-term benefit in BC. BC with a high percentage of lymphocytes has significantly demonstrated to be a predictive biomarker for response to NACT in early TNBC, with higher pCR (Table 2a). Regarding residual disease after NACT, higher residual-disease TILs are significantly associated with improved recurrence-free survival and OS [63]. Likewise, in the adjuvant setting, a higher density of TILs is associated with improved DFS, distant DFS and OS (Table $2 \mathrm{~b}$ ). It has been shown that a $10 \%$ increase in TILs has a good prognostic value when analyzed by uni- and multivariable adjusted survival analysis for DFS and OS [52-55] Therefore, it has been established as an independent prognostic factor for TNBC.

The variability in these outcomes probably depends not only on TIL quantity but also on the composition of lymphocytic infiltrates. CD8+ cytotoxic T lymphocytes are essential components of adaptive immunity involved in tumor cell destruction and expressed in $60 \%$ of TNBCs [62]. In a pooled analysis of 25 published studies, CD8+ lymphocytes were associated with improved and BC-specific survival [48]. Forkhead box protein $3(\mathrm{FoxP} 3+)$ is a specific molecular marker of $\mathrm{CD} 4+$ regulatory $\mathrm{T}$ cells (Tregs), found in $70 \%$ of TNBCs [62]. The role of FoxP3+ lymphocytes remains controversial since some studies reported improved PFS and OS although Tregs downregulate the antitumor activity of the immune system. It has also been shown that a higher CD8+/FoxP3+ ratio predicts more favorable outcomes in TNBC patients [64].

To standardize TILs evaluating the method in BC, the International TILs Working Group suggests assessing the percentage of TILs from the stromal compartment in hematoxylin- and eosin-stained tumor sections of a needle core biopsy.

\section{Immune Checkpoint Signaling Pathway}

The expression and interaction of the immune checkpoint molecules programmed death-1 (PD-1), its ligand PD-L1, and cytotoxic T lymphocyte-associated protein 4 (CTLA-4) are involved in T-cell activity regulation and tumor immune escape mechanisms, and they can be a therapeutic target to immune checkpoint inhibitors.

TNBC have the highest rate of PD-L1 expression, defined as at least $1 \%$ of PD-L1-positive cells, compared with other BC subtypes. PD-L1 expression on tumoral and inflammatory cells is significantly correlated with stromal TIL levels $[65,66]$, thus high PD-L1 levels have also been associated with an increased probability to achieve pCR after NACT and specific survival in TNBC [67]. Even though, recently, the Keynote-522 trial revealed that the addition of pembrolizumab to chemotherapy in the neoadjuvant setting significantly increased pCR and DFS both in PD-L1-positive or -negative subgroups [68]. Some authors found that patients with high PD-L1 expression and low levels of stromal TILs have the most unfavorable prognosis $[65,69]$, and probably those patients will benefit most from immunotherapy agents.

In the metastatic setting, PD-L1 has shown to be a clinical biomarker for the use of anti-PD-L1 agents like atezolizumab, with a notable benefit in terms of objective response rate, PFS, and OS (IMpassion-130 trial [70]). For pembrolizumab, data from the Keynote-086 study [71] suggest a modest benefit in the disease control rate for PD-L1 patients, with a long-lasting subset of patients with PD-L1-positive tumors. Combination therapy is currently under research, and the latest data have shown that combination chemotherapy with pembrolizumab increases PFS compared to chemotherapy only in patients with metastatic TNBC and PD-L1-positive tumors [72].

PD-L1 testing variability may depend on several factors, such as interpathologist variability or the use of different IHC assays. Studies conducted to standardize PDL1 testing in the clinical setting demonstrated concordant results using the 22C3, SP263, and 28-8 anti-PD-L1 antibodies in $\mathrm{BC}$ [73] and other tumors [74]; however, the SP142 assay seems to underestimate high PD-L1 positivity in approximately $20 \%$ of the tumors. In the same way, PD-L1 positivity can also be defined by different scoring systems: the percent tumor area covered by PD-L1-positive immune cells (IC score), assessed in atezolizumab trials, or the ratio of PD-L1-positive cells out of the total number of tumor cells (combined positive score), approved for pembrolizumab.

\section{Tumor Mutational Burden}

The presence of tumor antigenic epitopes, sprung from mutations in tumor cells, induces T-cell immune responses. $\mathrm{BC}$ is characterized by lower mutational loads than other tumors, but it varies among BC subtypes, with the highest average TMB for TNBC, followed by HER2+, and the lowest average for ER+. TMB-Hi tumors with a favorable immune-infiltrate disposition have been associated with a prolonged survival trend, but the statistical significance has not been achieved [75]. Further studies are needed to contrast this outcome.

\section{Immune Gene Expression Signature}

Several immune-related gene expression signatures have been described to typify the tumor immunogenicity 
Table 3. Immune gene signatures in triple-negative breast cancer (TNBC)

\begin{tabular}{|c|c|c|}
\hline Gene signatures & Gene lists & Association with clinical outcome \\
\hline $\begin{array}{l}\text { 7-gene expression } \\
\text { signature [76] }\end{array}$ & $\begin{array}{l}7 \text { genes related to immune/defense response (C1QA, IGLC2, LY9, TNFRSF17, } \\
\text { SPP1, XCL2, HLA-F) }\end{array}$ & $\begin{array}{l}\text { High immune response module } \\
\rightarrow \text { favorable prognosis in ER- BC }\end{array}$ \\
\hline $\begin{array}{l}\text { 14-gene HR-/TNBC } \\
\text { prognostic signature } \\
\text { index [77] }\end{array}$ & $\begin{array}{l}14 \text { prognostic genes (CXCL13, CLIC5, RGS4, RPS28, RFX7, EXOC7, HAPLN1, } \\
\text { ZNF3, SSX3, HRBL, PRRG3, ABO, PRTN3, MATN1) } \\
\text { including } 8 \text { genes linked to immune/inflammatory chemokine regulation }\end{array}$ & $\begin{array}{l}\text { High } \mathrm{HR}-/ \mathrm{TNBC} \text { index } \\
\rightarrow \text { poor prognosis in } \mathrm{HR}-\mathrm{BC}\end{array}$ \\
\hline $\begin{array}{l}\text { Ratio of high B cell and low } \\
\text { IL-8 metagenes [78] }\end{array}$ & $\begin{array}{l}\text { B-cell metagene including IgG } \\
\text { IL-8 metagene including } I L-8, C X C L 1, C X C L 2\end{array}$ & $\begin{array}{l}\text { High B-cell/low IL- } 8 \text { metagenes } \\
\rightarrow \text { favorable prognosis in TNBC }\end{array}$ \\
\hline $\begin{array}{l}\text { Optimized 5-gene } \\
\text { predictor (integrated cyto- } \\
\text { kine score) [79] }\end{array}$ & $\begin{array}{l}\text { Interferon } \gamma \text { - and IL-10-related pathway (TNFRSF17, CLIC5, HLA-F, CXCL13, } \\
X C L 2)\end{array}$ & $\begin{array}{l}\text { High integrated cytokine score } \\
\rightarrow \text { poor prognosis in HR- TNBC }\end{array}$ \\
\hline 4-gene signature [80] & $\begin{array}{l}\text { Expression levels of } 4 \text { genes (HLF, CXCL13, SULT1E1, GBP1) } \\
\text { predict the extent of lymphocytic infiltration after NACT }\end{array}$ & $\begin{array}{l}\text { High TILs after NACT } \\
\rightarrow \text { increase distant relapse-free survival }\end{array}$ \\
\hline
\end{tabular}

in different cancer types, including TNBC (Table 3) [7680]. In TNBC, a 4-gene signature including HLF, CXCL13, SULT1E1, and GBP1 showed correlation with the presence of high TILs after NACT and increased distant relapse-free survival in a multivariate analysis (HR 0.29, 95\% CI 0.13-0.67) [80]. Another 7-gene module including C1QA, IGLC2, LY9, TNFRSF17, SPP1, XCL2, and HLA-F showed immune response pathway activation and better prognosis in an ER-negative BC cohort [76]. Although available data strongly suggest that immune gene signature will be a useful approach for defining the immune characteristics of tumors, future research should be conducted to define a unified gene expression profile that can be implemented in clinical practice.

\section{Conclusion}

This review highlights the inherent problem related with the TNBC definition, as it does not reflect the complexity of this disease including intrinsic molecular and immunological heterogeneity, and a huge variety of clinical phenotypes. In the near future, a better comprehensive subclassification of TNBC incorporating new and complete panels of biomarkers and immune-molecular signatures should be considered for the design of future clinical trials in early and advanced TNBC.

\section{Acknowledgment}

We would like to thank Breast Care and Dr. Saura for the opportunity to perform this review focused on TNBC.

\section{Disclosure Statement}

Dr. Ciruelos reports personal fees from Roche, Lilly, Novartis, and Pfizer. The other authors have no conflicts of interest to declare.

\section{Funding Sources}

The author(s) received no specific funding for this work.

\section{Author Contributions}

All authors contributed equally to this manuscript.

\section{References}

1 Wolff AC, Hammond ME, Allison KH, Harvey BE, Mangu PB, Bartlett JM, et al. Human Epidermal Growth Factor Receptor 2 Testing in Breast Cancer: American Society of Clinical Oncology/College of American Pathologists Clinical Practice Guideline Focused Update. J Clin Oncol. 2018 Jul;36(20):2105-22.

2 Cortazar P, Zhang L, Untch M, Mehta K, Costantino JP, Wolmark N, et al. Pathological complete response and long-term clinical benefit in breast cancer: the CTNeoBC pooled analysis. Lancet. 2014 Jul;384(9938): 164-72.

3 Masuda N, Lee SJ, Ohtani S, Im YH, Lee ES, Yokota I, et al. Adjuvant Capecitabine for Breast Cancer after Preoperative Chemotherapy. N Engl J Med. 2017 Jun;376(22):214759.

4 Park JH, Jonas SF, Bataillon G, Criscitiello C, Salgado R, Loi S, et al. Prognostic value of tu- mor-infiltrating lymphocytes in patients with early-stage triple-negative breast cancers (TNBC) who did not receive adjuvant chemotherapy. Ann Oncol. 2019 Dec;30(12): 1941-9.

5 Nakagawa M, Bando Y, Nagao T, Morimoto M, Takai C, Ohnishi T, et al. Expression of p53, Ki-67, E-cadherin, N-cadherin and TOP2A in triple-negative breast cancer. Anticancer Res. 2011 Jun;31(6):2389-93. 
6 Wang W, Wu J, Zhang P, Fei X, Zong Y, Chen $\mathrm{X}$, et al. Prognostic and predictive value of Ki67 in triple-negative breast cancer. Oncotarget. 2016 May;7(21):31079-87.

7 Ilie SM, Bacinschi XE, Botnariuc I, Anghel RM. Potential clinically useful prognostic biomarkers in triple-negative breast cancer: preliminary results of a retrospective analysis. Breast Cancer (Dove Med Press). 2018 Nov; 10:177-94.

8 Ding Y, Ding K, Qian H, Yu X, Zou D, Yang $\mathrm{H}$, et al. Impact on survival of estrogen receptor, progesterone receptor and Ki-67 expression discordance pre- and post-neoadjuvant chemotherapy in breast cancer. PLoS One. 2020 Apr;15(4):e0231895.

9 Thike AA, Yong-Zheng Chong L, Cheok PY, Li HH, Wai-Cheong Yip G, Huat Bay B, et al. Loss of androgen receptor expression predicts early recurrence in triple-negative and basallike breast cancer. Mod Pathol. 2014 Mar; 27(3):352-60.

10 Rampurwala M, Wisinski KB, O’Regan R. Role of the androgen receptor in triple-negative breast cancer. Clin Adv Hematol Oncol. 2016 Mar;14(3):186-93. [cited 2020 May 1].

11 Cochrane DR, Bernales S, Jacobsen BM, Cittelly DM, Howe EN, D'Amato NC, et al. Role of the androgen receptor in breast cancer and preclinical analysis of enzalutamide. Breast Cancer Res. 2014 Jan;16(1):R7.

12 Bonnefoi H, Grellety T, Tredan O, Saghatchian M, Dalenc F, Mailliez A, et al. A phase II trial of abiraterone acetate plus prednisone in patients with triple-negative androgen receptor positive locally advanced or metastatic breast cancer (UCBG 12-1). Ann Oncol. 2016 May;27(5):812-8.

13 Traina TA, Miller K, Yardley DA, Eakle J, Schwartzberg LS, O’Shaughnessy J, et al. Enzalutamide for the Treatment of Androgen Receptor-Expressing Triple-Negative Breast Cancer. J Clin Oncol. 2018 Mar;36(9):884-90.

14 Gluz O, Liedtke C, Gottschalk N, Pusztai L, Nitz U, Harbeck N. Triple-negative breast cancer-current status and future directions. Ann Oncol. 2009 Dec;20(12):1913-27.

15 Gumuskaya B, Alper M, Hucumenoglu S, Altundag K, Uner A, Guler G. EGFR expression and gene copy number in triple-negative breast carcinoma. Cancer Genet Cytogenet. 2010 Dec;203(2):222-9.

16 Carey LA, Rugo HS, Marcom PK, Mayer EL, Esteva FJ, Ma CX, et al. TBCRC 001: randomized phase II study of cetuximab in combination with carboplatin in stage IV triple-negative breast cancer. J Clin Oncol. 2012 Jul; 30(21):2615-23.

17 Baselga J, Albanell J, Ruiz A, Lluch A, Gascón P, Guillém V, et al. Phase II and tumor pharmacodynamic study of gefitinib in patients with advanced breast cancer. J Clin Oncol. 2005 Aug;23(23):5323-33.

18 Cheang MC, Voduc D, Bajdik C, Leung S, McKinney S, Chia SK, et al. Basal-like breast cancer defined by five biomarkers has superior prognostic value than triple-negative phenotype. Clin Cancer Res. 2008 Mar;14(5):1368-76.

19 Ryu DW, Jung MJ, Choi WS, Lee CH. Clinical significance of morphologic characteristics in triple negative breast cancer. J Korean Surg Soc. 2011 May;80(5):301-6.
20 Dogu GG, Ozkan M, Ozturk F, Dikilitas M, Er O, Ozturk A. Triple-negative breast cancer: immunohistochemical correlation with basaloid markers and prognostic value of survivin. Med Oncol. 2010 Mar;27(1):34-9.

21 Lluch A, Barrios CH, Torrecillas L, Ruiz-Borrego $\mathrm{M}$, Bines J, Segalla J, et al.; GEICAM Spanish Breast Cancer Group; CIBOMA (Iberoamerican Coalition for Research in Breast Oncology); and LACOG (Latin American Cooperative Oncology Group). Phase III Trial of Adjuvant Capecitabine After Standard Neo-/Adjuvant Chemotherapy in $\mathrm{Pa}$ tients With Early Triple-Negative Breast Cancer (GEICAM/2003-11_CIBOMA/2004-01). J Clin Oncol. 2020 Jan;38(3):203-13.

22 Cancer Genome Atlas Network. Comprehensive molecular portraits of human breast tumours. Nature. 2012 Oct;490(7418):61-70.

23 Shah SP, Roth A, Goya R, Oloumi A, Ha G, Zhao Y, et al. The clonal and mutational evolution spectrum of primary triple-negative breast cancers. Nature. 2012 Apr;486(7403):395-9.

24 Duffy MJ, Synnott NC, Crown J. Mutant p53 in breast cancer: potential as a therapeutic target and biomarker. Breast Cancer Res Treat. 2018 Jul;170(2):213-9.

25 Cossu-Rocca P, Orrù S, Muroni MR, Sanges F, Sotgiu G, Ena S, et al. Analysis of PIK3CA Mutations and Activation Pathways in Triple Negative Breast Cancer. PLoS One. 2015 Nov; 10(11):e0141763.

26 Janku F, Yap TA, Meric-Bernstam F. Targeting the PI3K pathway in cancer: are we making headway? Nat Rev Clin Oncol. 2018 May; 15(5):273-91.

27 Hashimoto K, Tsuda H, Koizumi F, Shimizu C, Yonemori K, Ando M, et al. Activated $\mathrm{PI} 3 \mathrm{~K} / \mathrm{AKT}$ and MAPK pathways are potential good prognostic markers in node-positive, triple-negative breast cancer. Ann Oncol. 2014 Oct;25(10):1973-9.

28 Banerji S, Cibulskis K, Rangel-Escareno C, Brown KK, Carter SL, Frederick AM, et al. Sequence analysis of mutations and translocations across breast cancer subtypes. Nature. 2012 Jun;486(7403):405-9.

29 Kim SB, Dent R, Im SA, Espié M, Blau S, Tan $\mathrm{AR}$, et al.; LOTUS investigators. Ipatasertib plus paclitaxel versus placebo plus paclitaxel as first-line therapy for metastatic triple-negative breast cancer (LOTUS): a multicentre, randomised, double-blind, placebo-controlled, phase 2 trial. Lancet Oncol. 2017 Oct; 18(10):1360-72.

30 Schmid P, Abraham J, Chan S, Wheatley D, Brunt AM, Nemsadze G, et al. Capivasertib Plus Paclitaxel Versus Placebo Plus Paclitaxel As First-Line Therapy for Metastatic TripleNegative Breast Cancer: the PAKT Trial. J Clin Oncol. 2020 Feb;38(5):423-33.

31 Lord CJ, Ashworth A. PARP inhibitors: synthetic lethality in the clinic. Science. 2017 17; 355(6330):1152-8.

32 Robson M, Im SA, Senkus E, Xu B, Domchek SM, Masuda N, et al. Olaparib for Metastatic Breast Cancer in Patients with a Germline BRCA Mutation. N Engl J Med. 2017 Aug; 377(6):523-33.

33 Litton JK, Rugo HS, Ettl J, Hurvitz SA, Gonçalves A, Lee K-H, et al. Talazoparib in Patients with Advanced Breast Cancer and a
Germline BRCA Mutation. N Engl J Med. 2018 Aug;379(8):753-63.

34 Litton JK, Scoggins ME, Hess KR, Adrada BE, Murthy RK, Damodaran S, et al. Neoadjuvant Talazoparib for Patients With Operable Breast Cancer With a Germline BRCA Pathogenic Variant. J Clin Oncol. 2020 Feb;38(5): 388-94.

35 Jiang YZ, Ma D, Suo C, Shi J, Xue M, Hu X, et al. Genomic and Transcriptomic Landscape of Triple-Negative Breast Cancers: Subtypes and Treatment Strategies. Cancer Cell. 2019 Mar;35(3):428-440.e5.

36 De La Haba J, Guerrero-Zotano A, Perez-Fidalgo JA, Gonzalez Santiago S, Muñoz M, Andres R, et al. A phase II clinical trial to analyze olaparib response in patients with BRCA1 and/or BRCA2 promoter methylation with advanced breast cancer (GEICAM/2015-06 COMETA-Breast study). JCO. 2018 May; 36(15_suppl):TPS1114.

37 Pineda B, Diaz-Lagares A, Pérez-Fidalgo JA Burgués $\mathrm{O}$, González-Barrallo I, Crujeiras AB, et al. A two-gene epigenetic signature for the prediction of response to neoadjuvant chemotherapy in triple-negative breast cancer patients. Clin Epigenetics. 2019 Feb;11(1):33.

38 Stirzaker C, Zotenko E, Song JZ, Qu W, Nair SS, Locke WJ, et al. Methylome sequencing in triple-negative breast cancer reveals distinct methylation clusters with prognostic value. Nat Commun. 2015 Feb;6(1):5899.

39 Perou CM, Sørlie T, Eisen MB, van de Rijn M, Jeffrey SS, Rees CA, et al. Molecular portraits of human breast tumours. Nature. 2000 Aug; 406(6797):747-52.

40 Sørlie T, Perou CM, Tibshirani R, Aas T, Geisler S, Johnsen H, et al. Gene expression patterns of breast carcinomas distinguish tumor subclasses with clinical implications. Proc Natl Acad Sci USA. 2001 Sep;98(19):10869-74.

41 Badve S, Dabbs DJ, Schnitt SJ, Baehner FL, Decker T, Eusebi V, et al. Basal-like and triple-negative breast cancers: a critical review with an emphasis on the implications for pathologists and oncologists. Mod Pathol. 2011 Feb;24(2):157-67.

42 Prat A, Parker JS, Karginova O, Fan C, Livasy C, Herschkowitz JI, et al. Phenotypic and molecular characterization of the claudin-low intrinsic subtype of breast cancer. Breast Cancer Res. 2010;12(5):R68.

43 Chen X, Li J, Gray WH, Lehmann BD, Bauer JA, Shyr Y, et al. TNBCtype: A Subtyping Tool for Triple-Negative Breast Cancer. Cancer Inform. 2012;11:147-56.

44 Lehmann BD, Pietenpol JA. Identification and use of biomarkers in treatment strategies for triple-negative breast cancer subtypes. J Pathol. 2014 Jan;232(2):142-50.

45 Lehmann BD, Bauer JA, Chen X, Sanders ME, Chakravarthy AB, Shyr Y, et al. Identification of human triple-negative breast cancer subtypes and preclinical models for selection of targeted therapies. J Clin Invest. 2011 Jul; 121(7):2750-67.

46 Masuda H, Baggerly KA, Wang Y, Zhang Y, Gonzalez-Angulo AM, Meric-Bernstam F, et al. Differential response to neoadjuvant chemotherapy among 7 triple-negative breast cancer molecular subtypes. Clin Cancer Res. 2013 Oct;19(19):5533-40. 
47 Lehmann BD, Jovanović B, Chen X, Estrada MV, Johnson KN, Shyr Y, et al. Refinement of Triple-Negative Breast Cancer Molecular Subtypes: Implications for Neoadjuvant Chemotherapy Selection. PLoS One. 2016 Jun; 11(6):e0157368.

48 Burstein MD, Tsimelzon A, Poage GM, Covington KR, Contreras A, Fuqua SA, et al. Comprehensive genomic analysis identifies novel subtypes and targets of triple-negative breast cancer. Clin Cancer Res. 2015 Apr; 21(7):1688-98

49 Bareche Y, Venet D, Ignatiadis M, Aftimos P, Piccart M, Rothe F, et al. Unravelling triplenegative breast cancer molecular heterogeneity using an integrative multiomic analysis. Ann Oncol. 2018 Apr;29(4):895-902.

50 Bauer JA, Chakravarthy AB, Rosenbluth JM, Mi D, Seeley EH, De Matos Granja-Ingram N, et al. Identification of markers of taxane sensitivity using proteomic and genomic analyses of breast tumors from patients receiving neoadjuvant paclitaxel and radiation. Clin Cancer Res. 2010 Jan;16(2):681-90.

51 O'Loughlin M, Andreu X, Bianchi S, Chemielik E, Cordoba A, Cserni G, et al. Reproducibility and predictive value of scoring stromal tumour infiltrating lymphocytes in triple-negative breast cancer: a multi-institutional study. Breast Cancer Res Treat. 2018 Aug;171(1):1-9.

52 Loi S, Sirtaine N, Piette F, Salgado R, Viale G, Van Eenoo F, et al. Prognostic and predictive value of tumor-infiltrating lymphocytes in a phase III randomized adjuvant breast cancer trial in node-positive breast cancer comparing the addition of docetaxel to doxorubicin with doxorubicin-based chemotherapy: BIG 02-98. J Clin Oncol. 2013 Mar;31(7):860-7.

53 Loi S, Michiels S, Salgado R, Sirtaine N, Jose V, Fumagalli D, et al. Tumor infiltrating lymphocytes are prognostic in triple negative breast cancer and predictive for trastuzumab benefit in early breast cancer: results from the FinHER trial. Ann Oncol. 2014 Aug;25(8):1544-50.

54 Adams S, Gray RJ, Demaria S, Goldstein L, Perez EA, Shulman LN, et al. Prognostic value of tumor-infiltrating lymphocytes in triplenegative breast cancers from two phase III randomized adjuvant breast cancer trials: ECOG 2197 and ECOG 1199. J Clin Oncol. 2014 Sep;32(27):2959-66.

55 Pruneri G, Vingiani A, Bagnardi V, Rotmensz N, De Rose A, Palazzo A, et al. Clinical validity of tumor-infiltrating lymphocytes analysis in patients with triple-negative breast cancer. Ann Oncol. 2016 Feb;27(2):249-56.

56 Kotoula V, Chatzopoulos K, Lakis S, Alexopoulou Z, Timotheadou E, Zagouri F, et al. Tumors with high-density tumor infiltrating lymphocytes constitute a favorable entity in breast cancer: a pooled analysis of four prospective adjuvant trials. Oncotarget. 2016 Jan; 7(4):5074-87.

57 Denkert C, Loibl S, Noske A, Roller M, Müller BM, Komor M, et al. Tumor-associated lymphocytes as an independent predictor of response to neoadjuvant chemotherapy in breast cancer. J Clin Oncol. 2010 Jan;28(1): 105-13.

58 Denkert C, von Minckwitz G, Darb-Esfahani S, Lederer B, Heppner BI, Weber KE, et al. Tumour-infiltrating lymphocytes and prog- nosis in different subtypes of breast cancer: a pooled analysis of 3771 patients treated with neoadjuvant therapy. Lancet Oncol. 2018 Jan; 19(1):40-50.

59 Issa-Nummer Y, Darb-Esfahani S, Loibl S, Kunz G, Nekljudova V, Schrader I, et al. Prospective validation of immunological infiltrate for prediction of response to neoadjuvant chemotherapy in HER2-negative breast cancer-a substudy of the neoadjuvant GeparQuinto trial. PLoS One. 2013 Dec; 8(12):e79775.

60 Denkert C, von Minckwitz G, Brase JC, Sinn BV, Gade S, Kronenwett R, et al. Tumor-infiltrating lymphocytes and response to neoadjuvant chemotherapy with or without carboplatin in human epidermal growth factor receptor 2-positive and triple-negative primary breast cancers. J Clin Oncol. 2015 Mar;33(9): 983-91.

61 Herrero-Vicent C, Guerrera A, Gavilá J, Gozalbo F, Hernandez A, Sandiego S, et al. Predictive and prognostic impact of tumourinfiltrating lymphocytes in triple-negative breast cancer treated with neoadjuvant chemotherapy. Ecancermedicalscience. 2017 Aug; 11:759.

62 Stanton SE, Adams S, Disis ML. Variation in the Incidence and Magnitude of Tumor-Infiltrating Lymphocytes in Breast Cancer Subtypes: A Systematic Review. JAMA Oncol. 2016 Oct;2(10):1354-60.

63 Luen SJ, Salgado R, Dieci MV, Vingiani A, Curigliano G, Gould RE, et al. Prognostic implications of residual disease tumor-infiltrating lymphocytes and residual cancer burden in triple-negative breast cancer patients after neoadjuvant chemotherapy. Ann Oncol. 2019 Feb;30(2):236-42.

64 Miyashita M, Sasano H, Tamaki K, Hirakawa H, Takahashi Y, Nakagawa S, et al. Prognostic significance of tumor-infiltrating CD8+ and FOXP3+ lymphocytes in residual tumors and alterations in these parameters after neoadjuvant chemotherapy in triple-negative breast cancer: a retrospective multicenter study. Breast Cancer Res. 2015 Sep;17(1):124.

65 Mori H, Kubo M, Yamaguchi R, Nishimura R, Osako T, Arima N, et al. The combination of PD-L1 expression and decreased tumor-infiltrating lymphocytes is associated with a poor prognosis in triple-negative breast cancer. Oncotarget. 2017 Feb;8(9):15584-92.

66 Cerbelli B, Pernazza A, Botticelli A, Fortunato L, Monti M, Sciattella P, et al. PD-L1 Expression in TNBC: A Predictive Biomarker of Response to Neoadjuvant Chemotherapy? BioMed Res Int. 2017;2017:1750925.

67 Sabatier R, Finetti P, Mamessier E, Adelaide J, Chaffanet M, Ali HR, et al. Prognostic and predictive value of PDL1 expression in breast cancer. Oncotarget. 2015 Mar;6(7):5449-64.

68 Schmid P, Cortes J, Pusztai L, McArthur H, Kümmel S, Bergh J, et al. Pembrolizumab for Early Triple-Negative Breast Cancer. N Engl J Med. 2020 Feb;382(9):810-21.

69 Tomioka N, Azuma M, Ikarashi M, Yamamoto $\mathrm{M}$, Sato M, Watanabe KI, et al. The therapeutic candidate for immune checkpoint inhibitors elucidated by the status of tumor-infiltrating lymphocytes (TILs) and programmed death ligand 1 (PD-L1) expres- sion in triple negative breast cancer (TNBC). Breast Cancer. 2018 Jan;25(1):34-42.

70 Schmid P, Adams S, Rugo HS, Schneeweiss A, Barrios $\mathrm{CH}$, Iwata $\mathrm{H}$, et al.; IMpassion130 Trial Investigators. Atezolizumab and Nab-Paclitaxel in Advanced Triple-Negative Breast Cancer. N Engl J Med. 2018 Nov;379(22):2108-21.

71 Adams S, Schmid P, Rugo HS, Winer EP, Loirat $\mathrm{D}$, Awada $\mathrm{A}$, et al. Pembrolizumab monotherapy for previously treated metastatic triple-negative breast cancer: cohort A of the phase II KEYNOTE-086 study. Ann Oncol. 2019 Mar;30(3):397-404.

72 MERCK \& CO. INC. Merck's KEYTRUDA ${ }^{\circledR}$ (pembrolizumab) in Combination with Chemotherapy Met Primary Endpoint of Progression-Free Survival (PFS) as First-Line Treatment for Metastatic Triple-Negative Breast Cancer (mTNBC) [press release] (2020 Feb 12). Available from: https://investors. merck.com/news/press-release-details/2020/ Mercks-KEYTRUDA-pembrolizumab-inCombination-with-Chemotherapy-MetPrimary-Endpoint-of-Progression-FreeSurvival-PFS-as-First-Line-Treatment-forMetastatic-Triple-Negative-Breast-CancermTNBC/default.aspx.

73 Scott M, Scorer P, Barker C, Al-Masri H. 100 -Comparison of patient populations identified by different PD-L1 assays in in triple-negative breast cancer (TNBC). Ann Oncol. 2019 May;30(suppl_3):iii4.

74 Velcheti V, Patwardhan PD, Liu FX, Chen X, Cao X, Burke T. Real-world PD-L1 testing and distribution of PD-L1 tumor expression by immunohistochemistry assay type among patients with metastatic non-small cell lung cancer in the United States. PLoS One. 2018 Nov;13(11):e0206370.

75 Thomas A, Routh ED, Pullikuth A, Jin G, Su J, Chou JW, et al. Tumor mutational burden is a determinant of immune-mediated survival in breast cancer. OncoImmunology. 2018 Jul;7(10):e1490854.

76 Teschendorff AE, Miremadi A, Pinder SE, Ellis IO, Caldas C. An immune response gene expression module identifies a good prognosis subtype in estrogen receptor negative breast cancer. Genome Biol. 2007;8(8):R157.

77 Yau C, Esserman L, Moore DH, Waldman F, Sninsky J, Benz CC. A multigene predictor of metastatic outcome in early stage hormone receptor-negative and triple-negative breast cancer. Breast Cancer Res. 2010;12(5):R85.

78 Rody A, Karn T, Liedtke C, Pusztai L, Ruckhaeberle E, Hanker L, et al. A clinically relevant gene signature in triple negative and basal-like breast cancer. Breast Cancer Res. 2011 Oct;13(5):R97.

79 Yau C, Sninsky J, Kwok S, Wang A, Degnim A, Ingle JN, et al. An optimized five-gene multi-platform predictor of hormone receptor negative and triple negative breast cancer metastatic risk. Breast Cancer Res. 2013; 15(5):R103.

80 Criscitiello C, Bayar MA, Curigliano G, Symmans FW, Desmedt C, Bonnefoi $\mathrm{H}$, et al. A gene signature to predict high tumor-infiltrating lymphocytes after neoadjuvant chemotherapy and outcome in patients with triple-negative breast cancer. Ann Oncol. 2018 Jan;29(1):162-9. 